\title{
Two new genera of African whip scorpions (Schizomida: Hubbardiidae)
}

\section{Ава новых рода африканских шизомид (Schizomida: Hubbardiidae)}

\author{
Luis F. de Armas

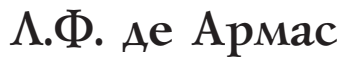 \\ P. O. Box 4327, San Antonio de los Baños, Artemisa 32500, Cuba. E-mail: luisdearmas1945@gmail.com \\ KEY WORDS: Hubbardiinae, taxonomy, Africa, Cameroon, Kenya, Liberia. \\ КЛЮЧЕВЫЕ СЛОВА: Нubbardiinae, систематика, Африка, Камерун, Кения, Либерия
}

\begin{abstract}
Two new hubbardiid genera and three new species are described from central Kenya, northeastern Cameroon and southwestern Liberia. Spermathecae of the Kenyan new genus and species, Kenyazomus pekkai sp.n., resemble those of the Australian Bamazomus bamaga Harvey, 1992, but the movable cheliceral finger lacks an accessory tooth (an accessory tooth is present in B. bamaga), the anterior margin of propeltidium has $1+1$ setal arrangement $(2+1$ in $B$. bamaga), and the pedipalps are sexually dimorphic (not so in the Australian species). The spermathecae of the new genus and species from Cameroon, Lawrencezomus atlanticus sp.n., roughly resemble those of the Australian Attenuizomus radon (Harvey, 1992), a taxon with female flagellum four-segmented and males having very attenuate abdomen and flagellum. The new species from Liberia, L. bong sp.n., is only known from a single male and two immature females, and its generic assignation is tentative.
\end{abstract}

РЕЗЮМЕ. Описаны два новых рода и три вида хуббардиид из центральной Кении, северо-восточного Камеруна и юго-западной Либерии. Сперматека кенийского нового рода и вида, Kenyazomus pekkai sp.n., похожа на таковую у Bamazomus bamaga Harvey, 1992, но не имеет дополнительного зубчика на подвижном пальце хелицер (дополнительный зубчик есть у $B$. bamaga), передний край пропельтидиума со щетинками 1+1 (2+1 у B. bamaga), и педипальпы диморфны у разных полов (мономорфны у австралийского вида). Сперматека у Lawrencezomus atlanticus sp.n., напоминает таковой у австралийского Attenuizomus radon (Harvey, 1992), имеющего 4-сегментный флагеллюм у самки и очень тонкое брюшко и флагеллюм у самца. Новый вид из Либерии, L. bong sp.n., описан по единственному самцу и двум неполовозрелым самкам. Вид включён в этот род условно.

\section{Introduction}

An important contribution to the study of the African schizomids was that of Lawrence [1969], in which the species all were included in the genus Schizomus Cook, 1899, a taxon now restricted to Sri Lanka and containing only two species [Reddell \& Cokendolpher, 1995; Harvey, 2003, 2011]. Most recent studies mainly deal with faunas of Somalia, Madagascar and Seychelles Islands [Harvey, 2001, 2006, 2010, 2011].

At this moment, the schizomid species from Madagascar and continental Africa are included in the hubbardiine genera Afrozomus Reddell et Cokendolpher, 1995 (monotypic; Angola and the Democratic Republic of Congo), Artacarus Cook, 1899 (monotypic; Liberia), Bamazomus Harvey, 1992 (Asia, Australia; three species in Madagascar), and Enigmazomus Harvey, 2006 (two species; Somalia and the Arabian peninsula), and the megaschizomine genus Megaschizomus Lawrence, 1969 (two species; Mozambique and South Africa) [Reddell \& Cokendolpher, 1995; Harvey, 2006, 2011]. Nevertheless, another eight species incorrectly remain under the genus name Schizomus, mainly because their female spermathecae are unknown [Reddell \& Cokendolpher, 1995; Harvey, 2001, 2003, 2006, 2011].

The African schizomid fauna has been poorly studied, and there is no doubt that the 11 genera and 30 species now listed from this continent and neighboring islands represent a small fragment of its whole fauna. For some African countries this arachnid order has not been recorded, whereas others have been poorly sampled.

In the present contribution, two new genera and three new species are described from Cameroon, Kenya, and Liberia.

\section{Material and methods}

This study was based on 17 specimens (two females, five males, 10 immatures) from Cameroon (one female, one male, and two immature females), Kenya (one female, three males, six immatures) and Liberia (one male, and two immature females). The specimens all are deposited in the Musée Royal de l'Afrique Centrale, Tervuren, Belgium (MRAC). 
Nomenclature follows Reddell \& Cokendolpher [1995]. Notation for tergites I-IX chaetotaxy is that of Harvey [1992]. Measurements are given in millimeters; total length excludes the flagellum. Spermathecae were studied after four hours mounted in lactophenol and posteriorly kept into micro-vials together with the corresponding specimen, in $75 \%$ ethanol. Drawings were made with Corel Draw 13 and Adobe Photoshop CS, based on photos taken with a Canon Powershot A1100 IS camera coupled to a dissection microscope (pedipalp, male flagellum, metapeltidium) or an optical microscope (chelicera, female genitalia and flagellum).

\section{Taxonomy}

Family Hubbardiidae Cook, 1899

Subfamily Hubbardiinae Cook, 1899

\section{Genus Kenyazomus gen.n.}

Type species: Kenyazomus pekkai sp.n.

DIAGNOSIS. The following combination of characters differentiate this taxon from other Hubbardiidae: anterior process of propeltidium with $1+1$ setal arrangement; pedipalps sexually dimorphic; male pedipalps armed. Female spermathecae resemble those of the Bamazomus species, but members of this genus have a distinct accessory tooth on the movable cheliceral finger, anterior process of propeltidium with $2+1$ setal arrangement, pedipalps not sexually dimorphic and male pedipalps without armature.

DESCRIPTION. Anterior process of propeltidium with a single seta followed by another one $(1+1)$; corneate eyes absent; metapeltidium clearly divided (Fig. 3A). Body without clavate setae. Pedipalps sexually dimorphic. Male pedipalps armed with strong mesal spur on trochanter and short, strong spiniform setae on ventroanterior surface of the femur (Figs 3 B-C). Movable cheliceral finger without accessory tooth, with a guard tooth at end of serrula (Figs 1A-B). Anterodorsal margin of femur IV produced at about a $90^{\circ}$ angle. Male abdomen not elongated, similar to female. Abdominal tergite II with two posterior setae. Abdominal segment XII of males with dorsal process (Figs 1C-D). Female flagellum three-segmented (Fig. 4D). Spermathecae consisting of numerous short lobes (Figs 4A-B), without nodules; gonopod not detected in the only female at hand.

ETYMOLOGY. The generic name is derived from Kenya, and the name Zomus Reddell \& Cokendolpher, 1995. It is masculine in gender.

REMARKS. The only African hubbardiid genera having the anterior process of propeltidium with $1+1$ setal arrangement are Afrozomus Reddell et Cokendolpher, 1995, Anepsiozomus Harvey, 2001, and Secozomus Harvey, 2001, as well as two species of uncertain generic status: "Schizomus" nidicolus Lawrence, 1969 from the Democratic Republic of Congo (Zaire), and
"Schizomus" mediocriter Lawrence, 1969 from Tanzania [Harvey, 2006: 173]. Females of Afrozomus machadoi (Lawrence, 1958) have the flagellum with four segments [Reddell \& Cokendolpher, 1995: 57, 142, table 4]. The female genitalia of Anepsiozomus sobrinus Harvey, 2001 from Seychelles comprise three pairs of spermathecal lobes, of which the internal pair have one large microtubule-bearing pore [Harvey, 2001: 686, fig. 7]. And female genitalia of Secozomus latipes (Hansen, 1905) from Seychelles comprise two pairs of spermathecal lobes, of which the mesal pair are rather bulbous, and the lateral pair possesses thin stalks with terminal bulb [Harvey, 2001: 688, fig. 9].

\section{Kenyazomus pekkai sp.n.}

Figs 1A-F, 2A-B, 3A-C, 4A-D; Table 1.

Holotype $\sigma^{7}$ (MRAC-215229), Kenya, Kirimeri forest, near Runyenyere, forest, beating, alt. $1700 \mathrm{~m}$, Jocqué \& Warui \& Vanden Spiegel, 26.IV.2004. Paratypes: 1 ( (MRAC-215299), same data as holotype; $1 O^{7}$ (MRAC-215382), same locality, forest, sieving litter, 26.IV.2004; 1 O 2 immatures ( $\sigma^{7} \&$ O) (MRAC-215389), same locality, forest, sieved litter, Winkler extraction, 26-27.IV.2004.

Other examined material: 1 immature $\sigma^{7}$ (MRAC-215221), same locality, forest, sieving litter, 26.IV.2004; 3 immature + (MRAC-215257), same locality, forest, sieved litter Winkler extraction, 27-28.IV.2004.

DISTRIBUTION. Only known from the type locality.

DIAGNOSIS. Propeltidium with two pairs of dorsal setae. Male flagellum with the bulb kidney-shaped in dorsal aspect, with two dorsomedian prominences (Figs 1C-D, 2A). Female flagellum without vm5 seta (Fig. 4E). The presence of abdominal numerous pairs of small lateral setae on segments X and XI (Fig. 1F) may be an autapomorphic character for this species (or the genus), but additional studies are needed on other hubbardiid schizomids for an elucidation of this hypothesis. By its bifurcate apex, and mesal spur on a large tubercle, the pedipalpal trochanter of K. pekkai $\mathrm{n}$. sp. resembles Heterozomus estor Armas et Viquez, 2010, from Guatemala, and Surazomus manaus Cokendolpher et Reddell, 2000, from Brazil, this being an uncommon character among schizomids.

Male. Dark brown-greenish, with leg tibiae and tarsi lighter; pedipalps slightly reddish, legs I pale brown. Propeltidium with two pairs of dorsal setae; ocular spots irregular in form. Metapeltidium divided (Fig. 3A). Anterior sternum with 9+2 setae. Cheliceral fixed finger with six accessory teeth; serrula on the movable finger with 18 hyaline teeth (Fig. 1B). Chaetotaxy: setal group formula: 3-2-2-2-7-1; G1 (setae group 1) with three spatulate setae, having $a-b$ (the most dorsal) the basal part almost smooth; basal part of the other (c) with scarce spinose spicules (Fig. 1A). Pedipalps (Figs 3B-C): trochanter apically pronounced, sharp-pointed, with a strong ventral longitudinal ridge, ventroanteriorly with a stout mesal tubercle ending in a large spur; femur 2.3 times longer than height, with three stout ventroanterior setae; patella 1.3 times longer than femur and 4.4 times longer than height. Chaeto- 

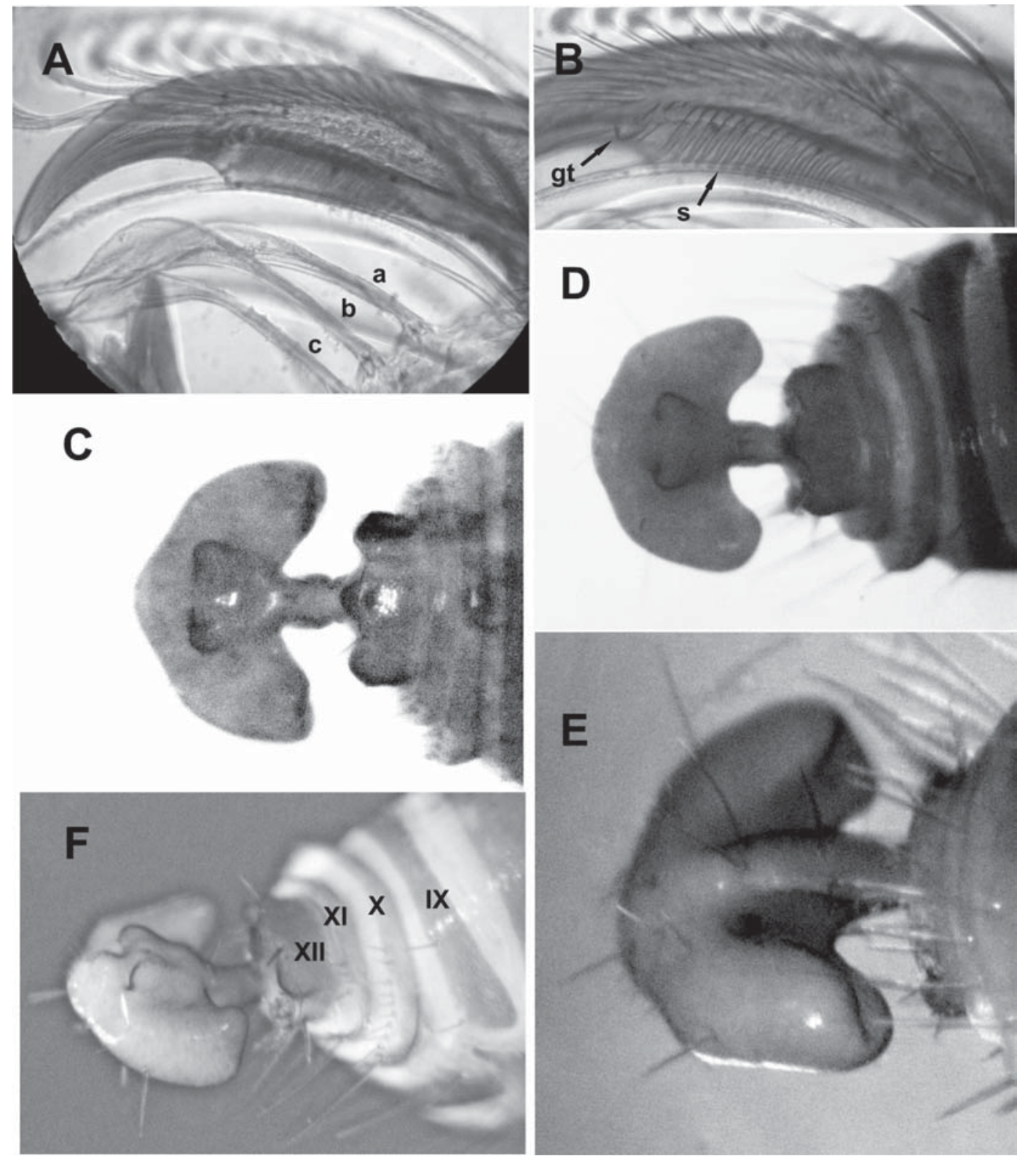

Fig. 1. Kenyazomus pekkai sp.n., male. A-B - chelicera, movable finger (paratype 215382): A - general aspect (a, b, c: setae group 1); B - serrula (s) and guard tooth (gt). C-F - last abdominal segments and flagellum: C-D - dorsal aspect of holotype (C) and paratype 215389 (D); E - ventral aspect of paratype 215389; F — dorsolateral aspect of paratype 215382, showing microsetae on abdominal segments X and XI.

Pис. 1. Kenyazomus pekkai sp.n., самец. А-B - хелицера, подвижный палец (паратип 215382): А — общий вид (a, b, c: группа щетинок 1); В - серрула (s) и защитный зубчик (gt). C-F - последние сегменты брюшка и флагеллюм: C-D - сверху у голотипа (C) и паратипа 215389 (D); E - снизу, паратип 215389; F — сверху-сбоку, паратип 215382, показаны щетинки на X и XI сегментах брюшка.

taxy of tergites I-IX: $2+4$ (microsetae diagonal): $2+6$ (microsetae in column): 2:2:2:2:2:4:4; segment $\mathrm{X}$ with nine pairs of small lateral setae (Fig. 1F); XI, with four pairs of small lateral setae; XII dorsoposteriorly trilobate, with the median eminence moderate, conic, flanked by two short setae. Flagellum resembles, at grosso modo, an arrow (Figs 1C-E, 2A-B); bulb 1.9 times wider than long, with two dorsomedian eminences; chaetotaxy: 19 setae ( 6 dorsal, 13 ventral), $\mathbf{d m} \mathbf{1}$ on the pedicel, dl1 distal to vl1 level, vm1 distal to vm2, dl3 in the apex, between $\mathbf{v m} \mathbf{4}$ and $\mathbf{v l} 2$ there are two pairs of setae, but vm5 is absent. Measurements (see Table 1).

Female (Figs 4A-E): Similar to the male, from which it differs by having unmodified pedipalps (Fig. 4C), abdominal segment XII without dorsal eminence, and flagellum three-segmented. Spermathecae (Fig. 4 A-B) consisting of 15-16 pairs of short, tubular spermathecal lobes, without nodules; chitinized arch heart- 


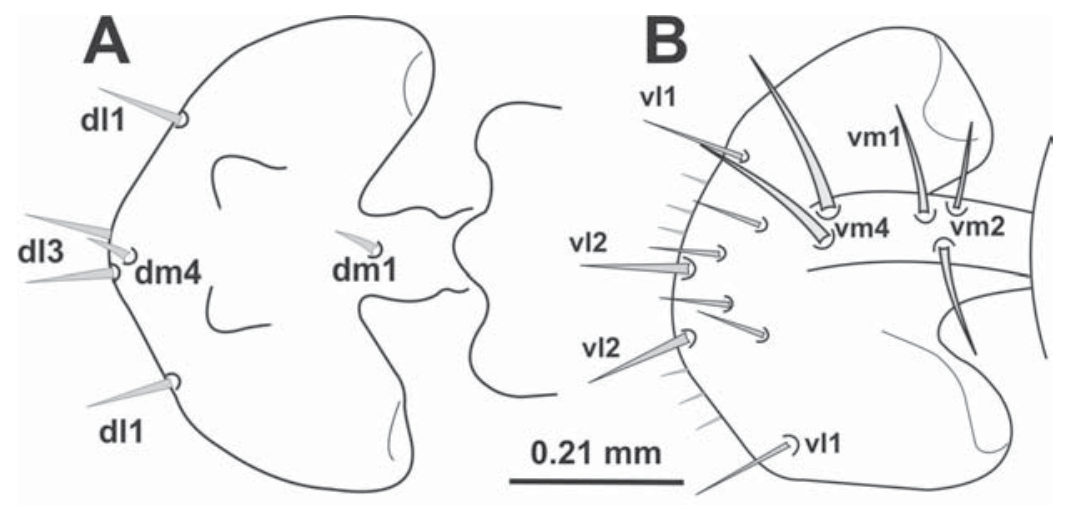

Fig. 2. Kenyazomus pekkai sp.n., male flagellum, chaetotaxy. A - dorsal; B ventral.

Рис. 2. Kenyazomus pekkai sp.n., флагеллюм самца, хетотаксия. А - сверху; В - снизу.

Fig. 3. Kenyazomus pekkai sp.n., male holotype. A - mesopeltidia (ms), metapeltidium (mt) and tergite I (t); B-C - pedipalps in external (B) and ventral (C); arrow indicate mesal spur on a large tubercle.

Рис. 3. Kenyazomus pekkai sp.n., caмец, голотип. А - мезопельтидии (ms), метапельтидиум (mt) и тергит I (t); BC - педипальпы сверху (B) и снизу (C); стрелка показывает средний шип на крупном бугорке.
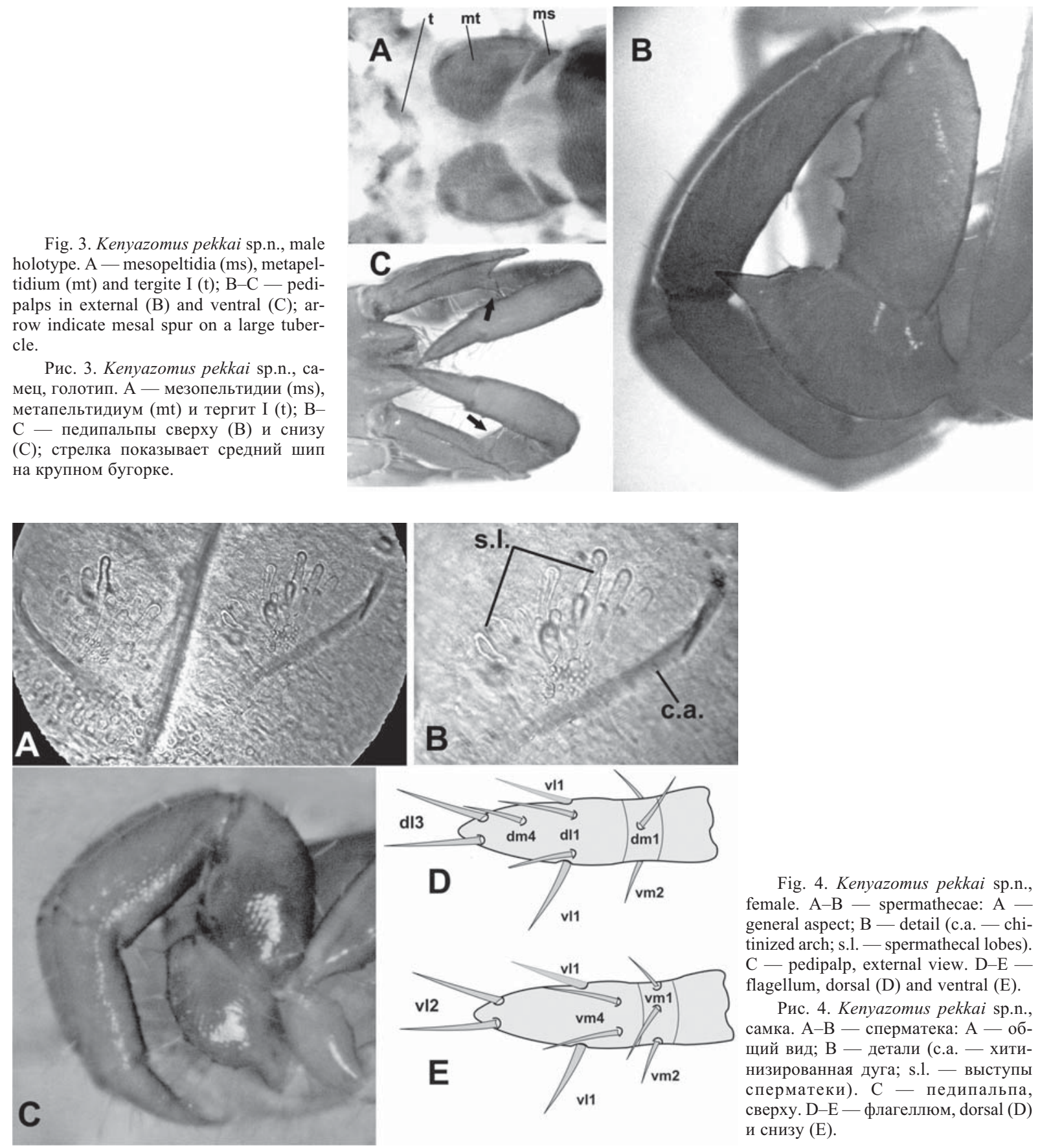

Fig. 4. Kenyazomus pekkai sp.n., female. A-B - spermathecae: A general aspect; B - detail (c.a. - chitinized arch; s.l. — spermathecal lobes). C - pedipalp, external view. D-E flagellum, dorsal (D) and ventral (E).

Рис. 4. Kenуazomus pekkai sp.n., самка. А-B - сперматека: А - общий вид; В - детали (с.а. - хитинизированная дуга; s.l. - выступы сперматеки). C - педипальпа, сверху. D-E - флагеллюм, dorsal (D) и снизу (E). 
Table 1. Measurements (in mm) of Kenyazomus pekkai sp.n. H — height; L — length; W — width.

Таблица 1. Промеры (в мм) Kenyazomus pekkai sp.n. H - высота; L — длина; W - ширина.

\begin{tabular}{|l|c|c|c|}
\hline \multirow{2}{*}{ Characters } & \multicolumn{2}{|c|}{ M a le s } & \multirow{2}{*}{ Female } \\
\cline { 2 - 3 } & Holotype & Paratype (215389) & 3.20 \\
\hline Total L & 3.60 & 3.50 & $1.04 / 0.54$ \\
\hline Propeltidium, L/W & $1.17 / 0.65$ & $1.09 / 0.65$ & (broken) \\
\hline Flagellum, L/W/H & $0.41 / 0.47 / 0.26$ & $0.41 / 0.57 / 0.26$ & 2.03 \\
\hline Pedipalp, L & 3.53 & 2.73 & $0.39 / 0.18$ \\
\hline Trochanter, L/H & $0.78 / 0.31$ & $0.65 / 0.28$ & $0.39 / 0.26$ \\
\hline Femur, L/H & $0.78 / 0.34$ & $0.60 / 0.28$ & $0.42 / 0.18$ \\
\hline Patella, L/H & $1.01 / 0.23$ & $0.70 / 0.21$ & 0.39 \\
\hline Tibia, L & 0.68 & 0.57 & 0.34 \\
\hline Tarsus, L & 0.28 & 0.21 & 3.54 \\
\hline Leg I, L & 4.39 & 4.43 & 0.26 \\
\hline Trochanter, L & 0.26 & 0.28 & 0.91 \\
\hline Femur, L & 1.06 & 1.15 & 0.99 \\
\hline Patella, L & 1.30 & 1.30 & 0.78 \\
\hline Tibia, L & 0.94 & 0.96 & 0.26 \\
\hline Basitarsus, L & 0.31 & 0.29 & 0.34 \\
\hline Telotarsus, L & 0.52 & 0.45 & 3.09 \\
\hline Leg IV, L & 3.53 & 3.56 & 0.26 \\
\hline Trochanter, L & 0.26 & 0.26 & $0.88 / 0.39$ \\
\hline Femur L/H & $1.04 / 0.41$ & $1.04 / 0.41$ & 0.44 \\
\hline Patella, L & 0.55 & 0.52 & 0.60 \\
\hline Tibia, L & 0.70 & 0.70 & 0.57 \\
\hline Basitarsus, L & 0.62 & 0.65 & 0.34 \\
\hline Telotarsus, L & 0.36 & 0.39 & \\
\hline
\end{tabular}

shaped, 1.7 times wider than long. Chaetotaxy of flagellum: second segment with $\mathbf{d m} \mathbf{1}, \mathbf{v m} \mathbf{1}$, and vm2; last segment without vm5 (Figs 4D-E). Measurements (Table 1).

ETYMOLOGY. The specific name is a patronymic in honor to the Finnish arachnologist Pekka T. Lehtinen, in his $80^{\text {th }}$ birthday, in recognition for his contributions on spiders and mites.

\section{Genus Lawrencezomus gen.n.}

Type species: Lawrencezomus atlanticus sp.n.

DIAGNOSIS. Lawrencezomus gen.n. can be distinguished from all other Hubbardiidae by the following combination of characters: Anterior process of propeltidium with $1+2$ setal arrangement; pedipalps sexually dimorphic; movable cheliceral finger without accessory tooth; females with a three-segmented flagellum (Figs $5 \mathrm{E} \mathrm{F}$ ); spermathecae consisting of two pairs of tubular lobes, not connected to each other basally (Fig. 5D); and abdominal segment XII of males with small dorsal process (Fig. 5A). The male flagellum of L. atlanticus sp. n. closely resembles that of Artacarus liberiensis Cook, 1899 from Liberia, a taxon having male pedipalps that are not sexually dimorphic, and female spermathecae with three pairs of lobes, each ending in an ovate bulb [Cokendolpher \& Reddell, 1987; Reddell \& Cokendolpher, 1995].
DESCRIPTION. Anterior process of propeltidium with a single seta followed by a pair of setae $(1+2)$; corneate eyes absent; metapeltidium entire (a fine median suture may be present). Body without clavate setae. Pedipalps sexually dimorphic (Fig. 5C). Male pedipalps without armature except for mesal spur on trochanter. Movable cheliceral finger without accessory tooth, with a guard tooth at end of serrula. Anterodorsal margin of femur IV produced at about a $90^{\circ}$ angle. Male abdomen not elongated, similar to female. Abdominal tergite II with two posterior setae. Abdominal segment XII of males with small dorsal process (Fig. 5A). Female flagellum three-segmented (Figs 5E-F). Spermathecae consisting of two pairs of tubular lobes, without terminal bulb and not connected to each other basally (Fig. 5D), without nodules; gonopod not detected in the only available female.

ETYMOLOGY. The generic name is derived from Lawrence [in honor of Reginald Frederick Lawrence (1897-1987), for his valuable contributions on African schizomids], and the name Zomus. It is masculine in gender.

Lawrencezomus atlanticus sp.n. Figs 5A-F, 7A; Table 2.

Holotype $O^{\top}$ (MRAC-221453), Cameroon, Atlantic Mountains $\left(08^{\circ} 31^{\prime} \mathrm{N}-12^{\circ} 36^{\prime} \mathrm{E}\right)$, litter among rocks, Winckler (sieving), 
Table 2. Measurements (mm) of two new species of the genus Lawrencezomus. H - height; L — length; W - width. Таблица 2. Промеры (в мм) двух новых видов рода Lawrencezomus. H — высота; L — длина; W — ширина.

\begin{tabular}{|c|c|c|c|}
\hline \multirow{2}{*}{ Characters } & \multicolumn{2}{|c|}{ Lawrencezomus atlanticus sp.n. } & L. bong sp.n. \\
\cline { 2 - 4 } & $\sigma^{7}$ Holotype & + Paratype & $\sigma^{7}$ Holotype \\
\hline Total L & 2.65 & 3.00 & 2.95 \\
\hline Propeltidium, L/W & $0.91 / 0.55$ & $0.88 / 0.49$ & $1.04 / 0.57$ \\
\hline Flagellum, L/W/H & $0.34 / 0.18 / 0.10$ & $0.18 / 0.05 / 0.05$ & $0.31 / 0.18 / 0.10$ \\
\hline Pedipalp, L & 2.31 & 1.58 & 3.30 \\
\hline Trochanter, L/H & $0.39 / 0.18$ & $0.31 / 0.18$ & $0.47 / 0.18$ \\
\hline Femur, L/H & $0.57 / 0.21$ & $0.39 / 0.21$ & $0.83 / 0.21$ \\
\hline Patella, L/H & $0.75 / 0.18$ & $0.39 / 0.16$ & $1.01 / 0.18$ \\
\hline Tibia, L & 0.42 & 0.31 & 0.73 \\
\hline Tarsus, L & 0.18 & 0.18 & 0.26 \\
\hline Leg I, L & 3.56 & 3.05 & - \\
\hline Trochanter, L & 0.26 & 0.26 & 0.26 \\
\hline Femur, L & 0.78 & 0.78 & 1.04 \\
\hline Patella, L & 1.06 & 0.80 & - \\
\hline Tibia, L & 0.78 & 0.62 & - \\
\hline Basitarsus, L & 0.26 & 0.23 & - \\
\hline Telotarsus, L & 0.42 & 0.36 & 3.22 \\
\hline Leg IV, L & 3.06 & 2.67 & 0.18 \\
\hline Trochanter, L & 0.26 & 0.21 & $0.99 / 0.42$ \\
\hline Femur, L/H & $0.91 / 0.39$ & $0.78 / 0.36$ & 0.42 \\
\hline Patella, L & 0.34 & 0.36 & 0.65 \\
\hline Tibia, L & 0.62 & 0.49 & 0.62 \\
\hline Basitarsus, L & 0.57 & 0.52 & 0.36 \\
\hline Telotarsus, L & 0.36 & 0.31 & \\
\hline & & & \\
\hline
\end{tabular}

Jocqué R., Loosveldt K., Baert L., Alderweireldt M., 5.V.2007. Paratype: 1 (MRAC-221453), same data as holotype.

Other examined material: 2 immature + + (MRAC-214975, and 221452), same data as holotype.

DISTRIBUTION. Only known from the type locality.

DIAGNOSIS. Male with pedipalps moderately elongate (Fig. 5C) and flagellum having the anterior margin of the bulb produced at about a $45^{\circ}$ angle (Fig. 5A).

Male. General color greenish brown, darker on abdominal tergites and legs IV; legs I pale yellowish brown. Propeltidium with two pairs of dorsal setae; anterior process with $1+2$ setal arrangement; eyespots elongate. Metapeltidium with a fine median suture. Anterior sternum with $11+2$ setae.

Cheliceral fixed finger with five accessory teeth. Movable finger without accessory tooth (Fig. 7A); serrula with 16 hyaline teeth; guard tooth moderate, oblong. Chaetotaxy: Setal group formula: 3-2-2-2-7-1; G1 (setae group 1) with three spatulate setae, which have the basal part furnished with two rows of spinose spicules.

Pedipalps (Fig. 5C): trochanter with mesal spur; apex scarcely prolonged beyond the femur point of insertion. Femur moderately attenuate, 2.7 times longer than high, with two spiniform setae on the ventroanterior surface and six on the dorsal margin. Patella 2.3 times longer than high. Tibia 0.9 times as long as the patella. Measurements (see Table 2).
Chaetotaxy of tergites I-IX: $2+4$ (microsetae diagonal): $2+6$ (microsetae in column): 2:2:2:2:2:4:4; segment $\mathrm{X}$ without dorsal setae; segment $\mathrm{XI}$ with two lateral setae; segment XII with small dorsal process. Flagellum lanceolate (Figs 5A-B), with 14 setae (6 dorsal, 8 ventral), dorsoventrally flattened, with a pair of dorsal submedian depressions; chaetotaxy: $\mathbf{d m} \mathbf{1}$ on the bulb, at level of vm1; vm5 present; vm2 distal to vm1; vm4 absent.

Female. Similar to the male, from which it differs by having unmodified pedipalps; metapeltidium entire, without median suture; abdominal segment XII without dorsal eminence, and flagellum three-segmented. Spermathecae (Fig. 5D) consisting of two pairs of tubular lobes, slightly widened at its base, the lateral pair smaller than the median, without terminal bulb and not connected to each other basally, without nodules; chitinized arch subrectangular, 2.6 times wider than long. Measurements (Table 2).

ANOMALOUS FEMALE FLAGELLUM. Immature + (MRAC-214975) has flagellum larger (0.26 long, $0.07 \mathrm{~mm}$ wide) and two-segmented (first two segments fused into a single one).

NATURAL HISTORY. The type series was collected in litter among rocks.

ETYMOLOGY. The specific name is derived from the type locality. 

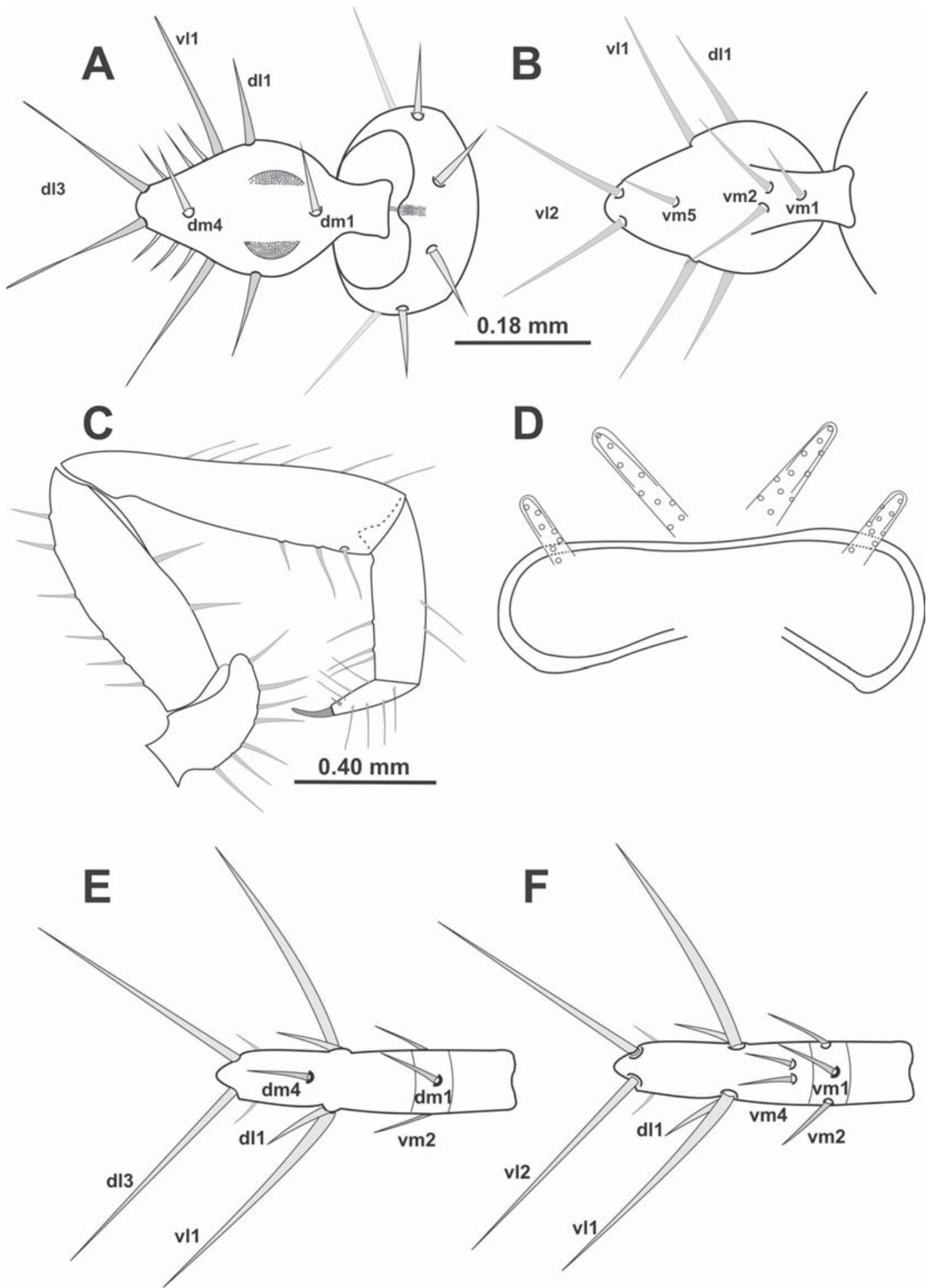

Fig. 5. Lawrencezomus atlanticus sp.n. A-C - male holotype. A-B - last abdominal segment and flagellum: A - dorsal; B ventral; C - pedipalp, lateral aspect. D-F - female: D - espermathecae; E-F - flagellum, dorsal (E) and ventral (F).

Рис. 5. Lawrencezomus atlanticus sp.n. A-C - голотип. А-B - последний сегмент брюшка и флагеллюм: А - сверху; В снизу; C - педипальпа, сбоку. D-F - самка: D - сперматека; E-F — флагеллюм, сверху (E) и снизу (F). 


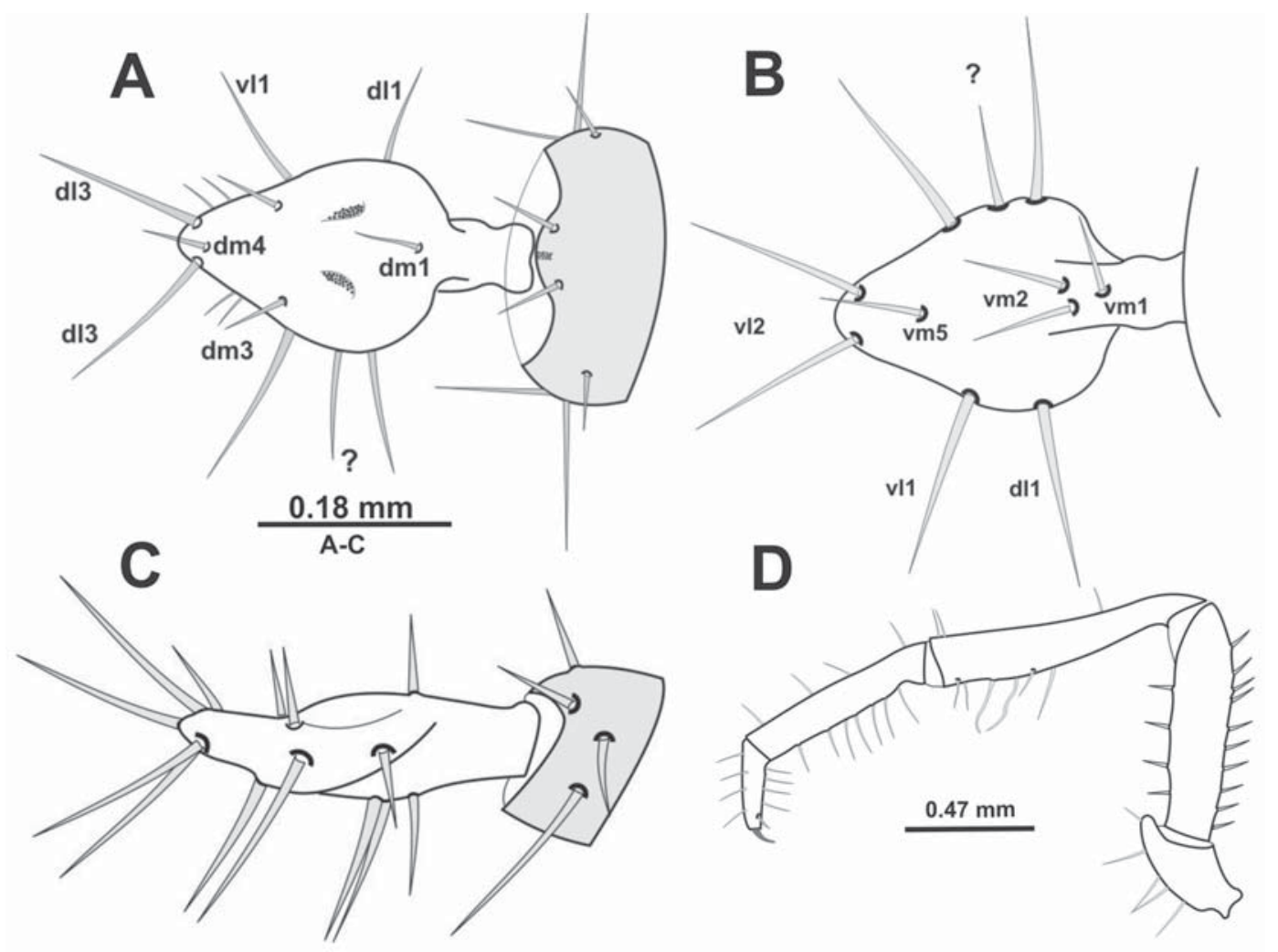

Fig. 6. Lawrencezomus bong sp.n., male holotype. A-C - last abdominal segment and flagellum: A - dorsal; B - ventral; C lateral. D - pedipalp, lateral aspect.

Рис. 6. Lawrencezomus bong sp.n., самец, голотип. А-C — последний сегмент брюшка и флагеллюм: А — сверху; В — снизу; C - сбоку. D - педипальпа, сбоку.

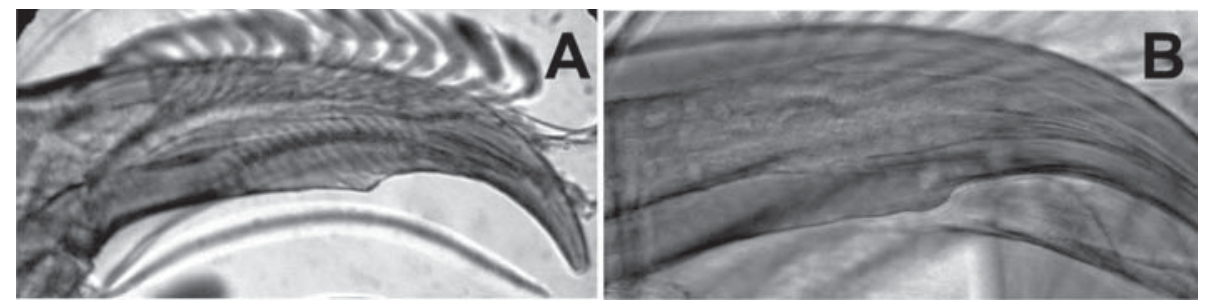

Fig. 7. Cheliceral movavle finger, lateral aspect. A - Lawrencezomus atlanticus sp.n., male holotype. B - L. bong sp.n., male holotype.

Рис. 7. Подвижный палец хелицеры, сбоку. А — Lawrencezomus atlanticus sp.n., голотип, самец. В — L. bong sp.n., голотип, самец.

REMARKS. After taken the first picture of the female genitalia, the microscopic slide was accidentally compressed and the median spermathecal lobes were displaced and the chitinized arch suffered distortion.

\section{Lawrencezomus bong sp.n.}

Figs 6A-D, 7B; Table 2.

Holotype: $\sigma^{7}$ (MRAC-216772), Liberia, Bong Range Forest $\left(06^{\circ} 49^{\prime} \mathrm{N}-10^{\circ} 17^{\prime} \mathrm{W}\right), 26 . \mathrm{III} .2005$, D. Flomo, pitfalls in rain forest.
Other examined material: 2 immature 우 (MRAC-216923 and 217075), same data as holotype.

DISTRIBUTION. Only known from the type locality.

DIAGNOSIS. This species clearly differs from $L$. atlanticus sp.n. by having anterior process of propeltidium with $1+1$ setal arrangement; male with more elongate pedipalps (Fig. 6D), and flagellum with anterior margin of the bulb almost right, with $\mathbf{d m} \mathbf{3}$ setae present (Figs 6A-C).

Male. General color pale yellowish brown. Propeltidium with two pairs of dorsal setae; anterior process 
with $1+1+1$ setal arrangement; eyespots almost indistinct. Metapeltidium entire. Anterior sternum with $11+2$ setae.

Cheliceral fixed finger with five accessory teeth. Movable finger without accessory tooth (Fig. 7B); serrula with 17 hyaline teeth; guard tooth large, oblong. Chaetotaxy: Setal group formula: 3-2-2-2-7-1; G1 (setae group 1) with three spatulate setae, which have the basal part furnished with two rows of spinose spicules.

Pedipalps (Fig. 6D). Trochanter with mesal spur; apex prolonged beyond the femur point of insertion. Femur attenuate, 4.0 times longer than high, with four spiniform setae on the ventroanterior surface and ten on the dorsal margin. Patella elongate, 5.6 times longer than high. Tibia 0.7 times as long as the patella. Measurements (see Table 2).

Chaetotaxy of tergites I-IX: $2+4$ (microsetae diagonal): $2+6$ (microsetae in column): 2:2:2:2:2:4:4; segment X without dorsal setae; segment XI with two lateral setae; segment XII with small dorsal process. Flagellum lanceolate (Figs 6A-B), with 17 setae (6 dorsal, 11 ventral), dorsoventrally flattened (Fig. 6C), with a pair of dorsal submedian depressions; setation: $\mathbf{d m} 1$ on the bulb, at level of vm1; dm3 and vm5 present; vm2 distal to vm1; vm4 absent; between dl1 and vl1 there is an asymmetric (supernumerary) seta.

Immature female. Anterior process of propeltidium with $1+1$ setal arrangement. Flagellum with tree segments; chaetotaxy: second segment with only $\mathbf{d m} \mathbf{1}$ and vm1; last segment with dl1, dm4, dl3, vm4 and vl2.

NATURAL HISTORY. The examined specimens were collected in the soil of a rain forest.

ETYMOLOGY. The specific name is a noun in apposition, taken from the type locality.

REMARKS. This species is tentatively included in this genus because the female spermathecae are unknown. It differs from Artacarus liberiensis Cook, 1899, from Liberia, and "Schizomus" brevicaudus (Hansen, 1921), from Boloma Island, Guinea-Bissau, by having attenuate male pedipalps (sexually dimorphic), and flagellum with pedicel longer, and the anterior margin of the bulb almost straight. Nevertheless, female genitalia are hitherto unknown for "Schizomus" brevicaudus and relationships among this three species cannot be established with confidence.

ACKNOWLEDGEMENTS. Didier van den Spiegel (RMCA) loaned the African schizomids deposited at his institution. Jans Morfe (Institute of Ecology and Systematics, Havana), kindly carried the specimens to Havana. Mark S. Harvey (Western Australian Museum, Australia) and an anonym referee also contributed with valuable suggestions and some aspects of English corrections to improve the final version. Special gratitude to Yuri M. Marusik for his kind patience in editing this manuscript.

\section{References}

Cokendolpher J.C., Reddell J.R. 1987. Supplementary descriptive notes on Schizomus liberiensis (Cook) (Schizomida, Schizomidae) // Journal of Arachnology. Vol.15. P.138-139.

Harvey M.S. 2001. The Schizomida (Arachnida) of the Seychelles Islands // Invertebrate Taxonomy. Vol.15. P.681-693.

Harvey M.S. 2003. Catalogue of the smaller arachnid orders of the World: Amblypygi, Uropygi, Schizomida, Palpigradi, Ricinulei and Solifugae. Collingwood Victoria, Australia: CSIRO Publishing. 385 pp.

Harvey M.S. 2006. The schizomid fauna (Arachnida: Schizomida: Hubbardiidae) of the Arabian Peninsula and Somalia // Fauna of Arabia. Vol.21. P.167-177.

Harvey M.S. 2010. Smaller arachnid orders. A synopsis of the smaller arachnid orders the Seychelles Islands (Arachnida: Pseudoscorpiones, Schizomida and Palpigradi) // Gerlach J. \& Marusik Y. (eds.). Arachnida and Myriapoda of the Seychelles Islands. Manchester, UK: Siri Scientific Press. P.331-340.

Harvey M.S. 2011. Notes on some Old World schizomids of the genera Ovozomus and Schizomus (Schizomida: Hubbardiidae) // Records of the Western Australian Museum. Vol.26. P.202208.

Lawrence R.F. 1969. The Uropygi (Arachnida: Schizomida) of the Ethiopian region // Journal of Natural History. Vol.3. P.217260.

Reddell J.R., Cokendolpher J.C. 1995. Catalogue, bibliography, and generic revision of the order Schizomida (Arachnida) // Texas Memorial Museum, Speleological Monographs. Vol.4. P.1-170.

Responsible editor Yu.M. Marusik 